\title{
The new Editorial Board of the International Review of the Red Cross
}

The editorial team of the Review has the privilege to introduce the new Editorial Board of the Journal. The Board was formed this year and met for the first time in Geneva in May 2011. It is composed of experts in multiple disciplines and from diverse geographical backgrounds.

The functions of the Editorial Board are to advise the editorial team, conduct peer reviews of articles, and guarantee the high academic quality of the Journal. The Editorial Board equally ensures that all relevant perspectives, both in terms of academic fields and geographic origins, are taken into account in exploring today's humanitarian challenges. The Board will convene once a year to take stock of the development of the editorial line of the Review and to select the future themes of the Review.

In order to enhance the Review's multidisciplinary and universal approach, lawyers, humanitarian practitioners, and social scientists from all over the world have been invited to join the new Board. Beyond their expertise in international law and international relations, the Board members bring a considerable wealth of experience in fields as diverse as military training, Islamic studies, history, sociology and humanitarian action.

The Review has a unique editorial line, situated at the crossroads between field realities, legal principles, and academic research. It is widely distributed to academic institutions, governments, and military legal circles by Cambridge University Press and by delegations of the International Committee of the Red Cross (ICRC) across the world. It benefits from an exceptional outreach, thanks to the yearly selections of articles in Arabic, Chinese, French, Spanish, and Russian and their web distribution. 
It is important to underline that the Review's main aim is to foster academic research on and understanding of international humanitarian law (IHL) and principled humanitarian action. The Review welcomes contributions of an academic nature by all academics and practitioners. The Editorial Board has a special role to play in ensuring the academic independence of the Journal.

The Review will continue to maintain and develop the highest academic standards in the field of international humanitarian law, policy, and action, with a view to contributing to academic research and influencing legal reasoning and policies. At its first meeting in May 2011, the Editorial Board confirmed the current main objectives, while adopting a new editorial strategy to ensure the continuous development of the Journal and increase its outreach. This strategy is based on the following elements:

- The Review aims to reflect current humanitarian affairs better, with a view to improving humanitarian and legal responses, and ultimately contributes to improving the situation of people affected by armed conflicts and other situations of violence. Renewed efforts will be devoted to the promotion of the Journal as a tool of influence.

- All editions will maintain a focus on a specific theme concerned with international humanitarian law, policy, and action of particular importance. While maintaining its reference position in IHL, the Review will endeavour in the coming years to attract more contributions on current humanitarian policy debates.

- The Review will reflect current debates and will seek and encourage diversity of perspectives, approaches, and geographic origins of contributions. In particular, the Board is interested in exploring current legal and humanitarian policy gaps with a view to developing innovative responses.

The Editorial Board has already selected the future themes of the Review for the period March 2012-March 2013, according to their relevance and academic interest. Authors are encouraged to send their submissions to the Journal on relevant topics and preferably in the following areas:

1. March 2012 : Occupation

2. June 2012: New technologies and warfare

3. September 2012: Business, violence, and conflicts

4 December 2012: Health care in conflict

5. March 2013: The ICRC in international relations (150th anniversary of the ICRC)

The editorial team of the Review takes this opportunity to thank the members of the previous Editorial Board (2004-2010) for their contribution to the quality and influence of the Journal. 


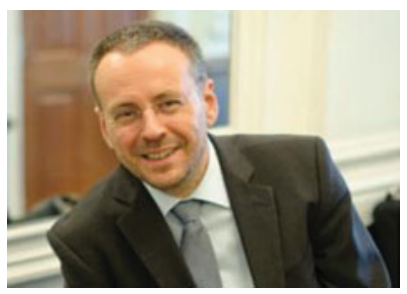

\section{Vincent BERNARD (France), Editor-in- Chief of the International Review of the Red Cross (ICRC Geneva)}

Vincent Bernard became Editor-in-Chief of the International Review of the Red Cross in October 2010. A graduate of Strasburg's Political Sciences Institute, he holds a Masters degree in political sciences, an LLM in international law (Law faculty in Strasburg and King's College London) and a DES in international relations from the Geneva Graduate Institute of International Studies. He won the IHL Jean Pictet competition as part of the Graduate Institute's team in 1995. After lecturing on international law and IHL at the University of Marmara in Istanbul, he joined the ICRC in 1998. He has worked for the institution for thirteen years, both in the field (Regional Delegation for West Africa in Dakar, Regional Delegation for East Africa in Nairobi, and Israel and Occupied territories) and at headquarters, and in various areas and capacities (integration and promotion of IHL, communication co-ordinator, head of sector for Africa, and head of operational communication).

Vincent Bernard (C) ICRC

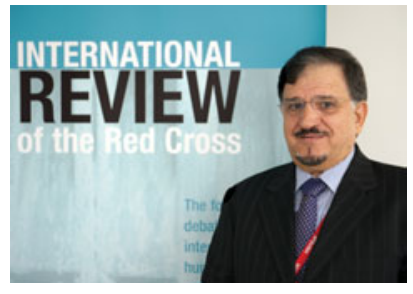

\section{Rashid Hamad AL ANEZI, Professor of International Law (Kuwait)}

Rashid Hamad Al Anezi is Professor of International Law, Kuwait University School of Law. He holds a PhD from the University of Cambridge (1989), an LLM from Tulane University, USA, and a BA in Law and Sharia from Kuwait University. He was Assistant Dean for the Faculty of Law and Head of the International Law Department. He is currently a Partner at the law firm International Legal Group. He is a permanent member of various ministerial committees, including the national committee on IHL. He is a member of the Board of Editors of the Law Journal issued by the Kuwait Lawyers Association and the Law Journal of Kuwait University School of Law. He is the author of many articles and books on international law and IHL.

Rashid Hamad Al Anezi (C) ICRC

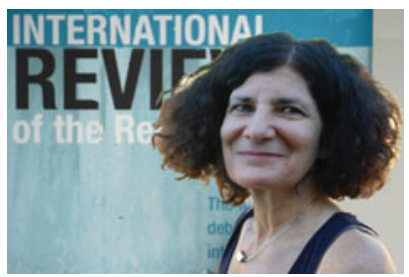

\section{Annette BECKER, Professor of Modern History (France)}

Annette Becker, Professor of Modern History at Paris Ouest Nanterre La Défense and a senior member of the Institut Universitaire de France, has written extensively 
on the two World Wars and the extreme violence that they inflicted upon civilians, with an emphasis on military occupation and genocide. She has devoted research to humanitarian politics, trauma, and memories, particularly among intellectuals and artists. Her most recent books were Apollinaire: Une biographie de guerre (2009) and Les cicatrices Rouges: France et Belgique occupées 1914-1918 (2010). She is now writing on two important voices of the twentieth century and its catastrophes, Raphael Lemkin and Jan Karski.

Annette Becker (C) ICRC

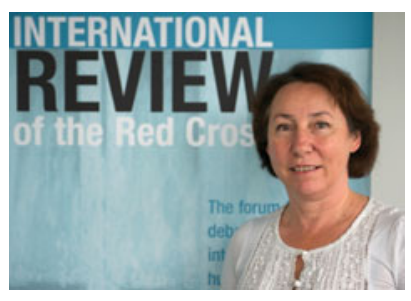

\section{Françoise BOUCHET-SAULNIER, Legal Director of Médecins sans Frontières (France)}

Françoise Bouchet-Saulnier, a Doctor of Law and magistrate, is the Legal Director of Médecins sans Frontières (MSF) and former Research Director at the Fondation Médecins sans Frontières. She is the author of several books and articles on humanitarian work, humanitarian law, and international justice, in particular the Practical Guide to Humanitarian Law/ Dictionnaire pratique du droit humanitaire (2007) and a book on Rwanda, Maudits soient les yeux fermés (1995). She is involved in framing the rights and responsibilities of MSF humanitarian and medical activities in situations of armed conflict or internal tension, as well as medical rights and duties when treating the sick, wounded, and victims of sexual violence and interacting with judicial systems. She currently teaches Masters courses at the Paris Institute of Political Studies and at the Paris Catholic Institute.

Françoise Bouchet-Saulnier @ ICRC

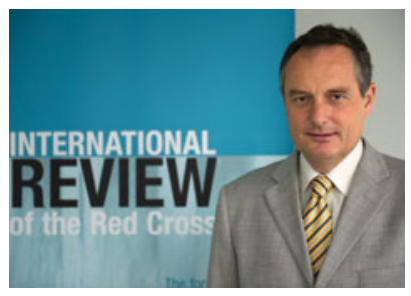

\section{Alain DELETROZ (Switzerland), Vice-President of International Crisis Group (Belgium)}

Alain Délétroz is a Swiss and French national. He concentrates on European policy and advocacy issues, closely focused on the European Union (EU) and its member states. He maintains senior-level contacts and advocates International Crisis Group (ICG) recommendations to officials in Brussels, Latin America, the EU member states, and Russia. He pays regular advocacy visits to these countries and gives interviews to their media on the conflicts that ICG covers. His areas of expertise include Russia, Northern/Southern Caucasus, and Central Asia; Latin America; conflict assessment and conflict resolution; democratic reforms; and humanitarian assistance. His professional 
background includes: Director, Open Society Institute, Tashkent, 1986-2001; International Committee of the Red Cross, Moscow, 1994-1998; Adult literacy and capacity-building projects, Peru, 1986-1991.

Alain Délétroz @ ICRC

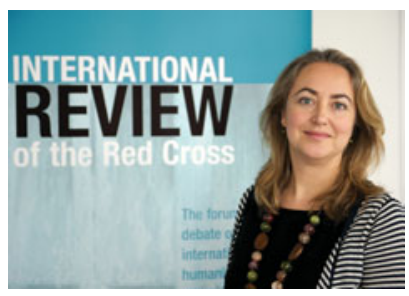

\section{Helen DURHAM, Legal Advisor for the Australian Red Cross (Australia)}

Helen Durham is the Strategic Adviser, International Law, for the Australian Red Cross and a Senior Fellow at Melbourne Law School. She has a PhD in the area of IHL and international criminal law and has been admitted as a barrister and solicitor of the Supreme Court of Victoria and High Court of Australia. Helen has worked as Head of Office, ICRC Sydney and Legal Adviser to the ICRC Regional Delegation of the Pacific, and has carried out a number of short missions with the ICRC in Burma, Aceh, and the Philippines. In 2006-2008 she held the position of Director, Research and Development, with the Asia Pacific Centre for Military Law and was previously IHL Manager of Australian Red Cross. She has published a number of edited books and articles on IHL and her most recent co-authored book is Documents on the Law of UN Peace Operations (2010). She currently teaches in the Melbourne Law Masters programme at Melbourne Law School and has a number of research projects focusing on topics such as the Responsibility to Protect (R2P) and IHL, the legal framework of the international deployment of police, and gender and IHL.

Helen Durham @ ICRC

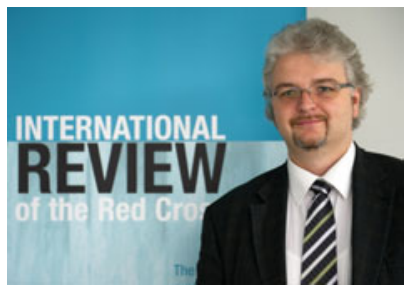

\section{Mykola M. GNATOVSKYY, Professor of International Law (Ukraine)}

Mykola Gnatovskyy is Associate Professor of International Law at the Institute of International Relations, Kyiv National Taras Shevchenko University, where he teaches IHL, international criminal law, and general international law. $\mathrm{He}$ is a member of the European Committee for the Prevention of Torture and Inhuman or Degrading Treatment or Punishment. He is also Academic Secretary of the Ukrainian Association of International Law, Deputy Editor-in-Chief of the Ukrainian Journal of International Law, and Executive Editor of the Ukrainian Yearbook of International Law. He is the author of a number of publications on IHL, human rights, and international criminal law.

Mykola Gnatovskyy (C ICRC 


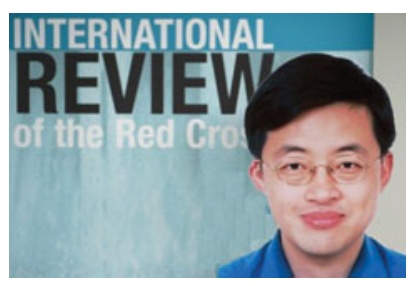

\section{Bing Bing JIA, Professor of International Law (China)}

Bing Bing Jia is Professor of Law at Tsinghua University School of Law, Beijing. He has an LLB from Peking University (1989) and a DPhil from the University of Oxford (1995). His field of expertise lies in general international law, IHL, and international criminal law.

He has worked as a Legal Officer for the Appeals Chamber of the United Nations International Criminal Tribunal for the former Yugoslavia (The Hague) (ICTY), 2002-2004; as a Legal Officer for the Trial Chamber III of the ICTY, 2000-2002; as an Associate Legal Officer in the Appeals Chambers of the ICTY and of the International Criminal Tribunal for Rwanda (ICTR), 1998-2000; and as a Law Clerk in the Appeals Chambers of the ICTY and ICTR, 1996-1998. He is the author of several publications on public international law and international criminal justice in particular.

Bing Bing Jia @ ICRC

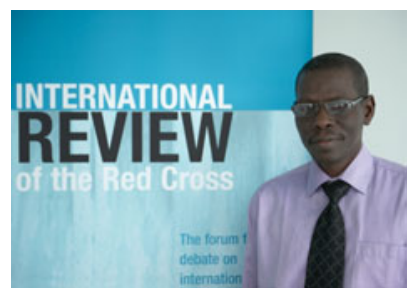

\section{Abdul Aziz KÉBÉ, University teacher in Islamic Studies (Senegal)}

Abdoul Aziz Kébé is a university teacher in Islamic Studies at the Arabic Department of the Cheikh Anta Diop University in Dakar. He is a leading member of the Tijaniya Brotherhood in Senegal, and an important analyst of society, the state, and Islam in West Africa. $\mathrm{He}$ is an active figure in Senegalese civil society, campaigning for women's rights, against female circumcision, and for the prevention of AIDS/HIV. He is well known and well connected with universities, religious institutions, and leaders in West Africa and the Middle East. He has worked as an expert and consultant for various different international organizations and UN bodies. In co-operation with the ICRC, he runs a programme for postgraduate students in his university under the title 'Islam: sociétés en mutation'. As an external expert, advisor, and friend of the ICRC, he has attended several networking meetings organized by the global affairs unit in Africa since 2006.

Abdoul Aziz Kébé @ ICRC

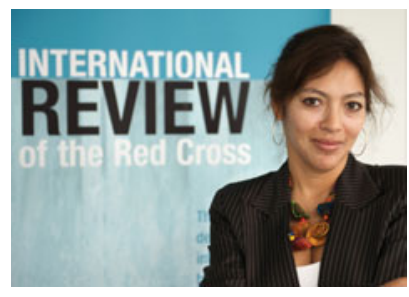

\section{Elizabeth SALMÓN, Professor of International Law (Peru)}

Elizabeth Salmón is Professor of the Peru School of Law at the Pontifical Catholic University and Academic Director of the Institute for Democracy and Human Rights of the same university (IDEHPUCP), where she 
co-ordinates the Human Rights Master Programme. She holds a Doctorate in International Law from the University of Seville and is the author of several publications on public international law, international human rights law, international criminal law, IHL, and transitional justice. She is a former consultant to the Ministry of Justice, the Ministry of Defence, the Peruvian Truth and Reconciliation Commission, the United Nations, and the ICRC; she is also visiting professor at the University of Bordeaux in France and the University Externado of Colombia.

Elizabeth Salmón @ ICRC

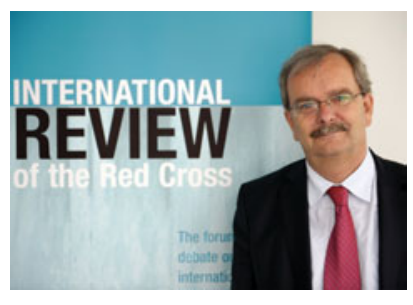

\section{Marco SASSÒLI, Professor of International Law (Switzerland)}

Marco Sassòli, a national of Switzerland and Italy, is professor and director of the Department of International Law and International Organization of the University of Geneva. From 2001 to 2003, he was Professor of International Law at the University of Québec in Montréal, where he remains Associate Professor. He chairs the Board of Geneva Call, an NGO that engages with armed non-state actors to adhere to humanitarian norms. He is also Vice-Chair of the Board of the International Council of Human Rights Policy. He graduated as a Doctor of Laws from the University of Basel (Switzerland) and is a member of the Swiss Bar. He has also served as Executive Secretary of the International Commission of Jurists and as Registrar at the Swiss Supreme Court. He worked from 1985 to 1997 for the ICRC, both at its headquarters in Geneva, inter alia as deputy head of its legal division, and in the field, inter alia as head of delegation in Jordan and Syria, and as protection coordinator for the former Yugoslavia. In 2011, he took a sabbatical in order to take up a six-month assignment as the legal adviser for the ICRC in Pakistan.

Marco Sassòli @ ICRC

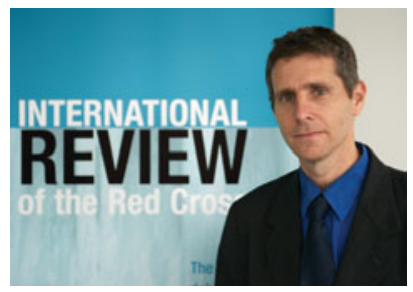

\section{Yuval SHANY, Professor of International Law (Israel)}

Yuval Shany holds the Hersch Lauterpacht Chair in International Law at the Law Faculty of the Hebrew University of Jerusalem. He also currently serves as a board member in the International Law Forum at the Hebrew University, a director in the Project on International Courts and Tribunals (PICT), a member of the steering committee of the DOMAC project (assessing the impact of international courts on domestic criminal procedures in mass atrocity cases), and as senior research fellow at the Israel Democracy Institute. He holds degrees in law from the Hebrew University (LLB, 1995 
cum laude), New York University (LLM, 1997) and the University of London (PhD, 2001). He has published a number of books and articles on international courts and arbitration tribunals and other international law issues such as international human rights and IHL. He was the recipient of the 2004 American Society of International Law book award (creative legal scholarship) and a 2008 recipient of a European Research Council grant awarded to pioneering research leaders. He has taught in a number of law schools in Israel, and in recent years has been a research fellow in Harvard and Amsterdam Universities and a visiting professor at the Georgetown University Law Center, Michigan University Law School, Columbia University Law School, and the Faculty of Law of the University of Sydney.

Yuval Shany @ ICRC

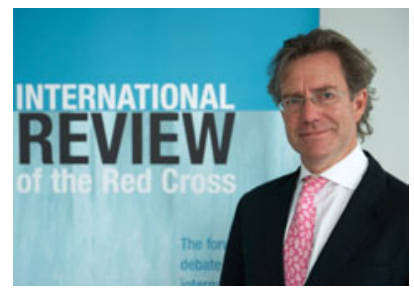

\section{Hugo SLIM, Visiting Fellow at the Oxford Institute for Ethics, Law and Armed Conflict (UK)}

Hugo Slim has worked in academia, humanitarian agencies, and business. He managed humanitarian operations with Save the Children UK and the United Nations in Morocco, Sudan, Ethiopia, Bangladesh, and the Middle East from 1983 to 1993. He was Reader in International Humanitarianism at Oxford Brookes University from 1994 to 2003 and has led major evaluations of humanitarian and development work across Africa for many of the world's leading UN agencies and NGOs. He has been a board member of Oxfam GB and an international advisor to the British Red Cross. From 2003 to 2007, he was Chief Scholar at the Centre for Humanitarian Dialogue in Geneva, where he led major research on the protection of civilians. In 2007, he was a founding Director of Malachite, and is responsible for building the company's international consultancy from the UK. He has led Malachite teams in twelve African countries, India, and Iraq. He is an award-winning academic and the author of Killing Civilians: Method, Madness and Morality in War (2007) and more than sixty academic papers. He has an MA in Theology from the University of Oxford and a $\mathrm{PhD}$ in Humanitarian Ethics from Oxford Brookes University. He is currently a Visiting Fellow at the Oxford Institute of Ethics, Law and Armed Conflict at the University of Oxford.

Hugo Slim @ ICRC

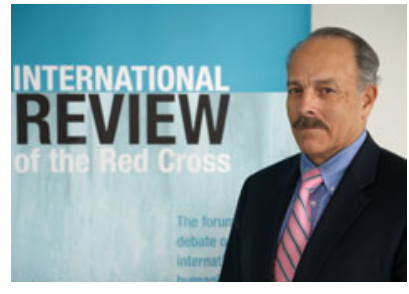

\section{Gary D. SOLIS, Adjunct Professor of Law (USA)}

Gary Solis teaches the law of war at Georgetown University Law Center and George Washington University Law School. He is a retired Professor of Law of the United States Military Academy and for six 
years directed West Point's law of war programme. He was a 2007 Library of Congress scholar in residence. He is a retired Marine Corps lieutenant-colonel with twenty-six years' active service, having twice served in Vietnam. His law degrees are from the University of California at Davis and George Washington University. His doctorate (law of war) is from the London School of Economics \& Political Science, where he subsequently taught for three years. His books are Marines and Military Law in Vietnam (1989), Son Thang: an American War Crime (1997), and The Law of Armed Conflict (2010; 2011 ASIL Certificate of Merit).

Gary D. Solis (C ICRC

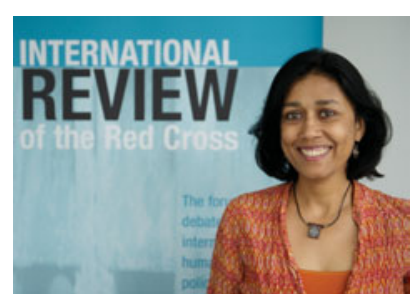

\section{Nandini SUNDAR, Professor of Sociology (India)}

Nandini Sundar is Professor of Sociology at the Delhi School of Economics, Delhi University. From 2007 to 2011, she co-edited the leading Indian sociological journal, Contributions to Indian Sociology. Her publications include Subalterns and Sovereigns: An Anthropological History of Bastar (2nd edition, 2007) and Branching Out: Joint Forest Management in India (2001), as well as several edited volumes. In 2010 she was awarded the Infosys Prize for Social Sciences - Social Anthropology in 'recognition of her contributions as an outstanding analyst of social identities, including tribe and caste, and the politics of knowledge in modern India'. She has been a member of a number of government committees concerning the welfare of Scheduled Tribes (indigenous peoples), as well as serving on the boards of research institutions and NGOs. Since 2005 she has been engaged in a major campaign against violations of human rights and humanitarian law in central India, including litigation in the Indian Supreme Court, on behalf of indigenous people among whom she has worked for many years. Her current interests relate to citizenship, war, and counterinsurgency in South Asia, indigenous identity and politics in India, the sociology of law, and inequality. Her public writings are available at http:// nandinisundar.blogspot.com

Nandini Sundar @ ICRC

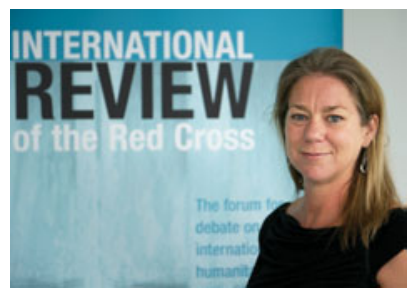

Fiona TERRY, Independent researcher on humanitarian action (Australia)

Fiona Terry has spent most of the last twenty years involved in humanitarian operations in different parts of the world, including Northern Iraq, Somalia, the Great Lakes region of Africa, Liberia, and Sudan. She was a research director for Médecins Sans Frontières in 
Paris from 2000 to 2003, working on North Korea, Sierra Leone, and Angola, before spending three years with the ICRC in Myanmar (Burma). She holds a PhD in international relations and political science from the Australian National University and is the author of Condemned to Repeat? The Paradox of Humanitarian Action (2002), which won the 2006 Grawemeyer Award for Ideas Improving World Order. More recently she has been teaching at Duke University in North Carolina, and has undertaken several in-depth studies for the ICRC, including on the practice of neutrality in Sudan and Afghanistan and on the protection of health care in Afghanistan. She is currently based in Kathmandu, Nepal.

Fiona Terry @ ICRC

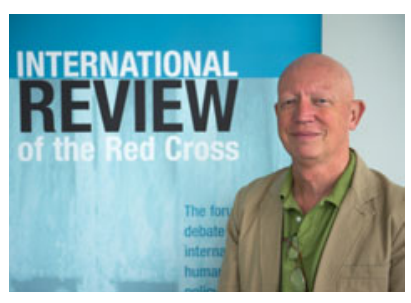

\section{Peter WALKER (UK), Director of the Feinstein International Center, Tufts University, Boston (USA)}

Director of the Feinstein International Center since September 2002 and active in development and disaster response since 1979, Peter Walker has worked for a number of British-based NGOs and environmental organizations in several African countries, and has been both a university lecturer and director of a food wholesaling company. He joined the International Federation of Red Cross and Red Crescent Societies in Geneva in 1990, where he was Director of Disaster Policy for ten years before moving to Bangkok as Head of the Federation's regional programmes for Southeast Asia. He has travelled extensively in the Middle East, Africa, Eastern Europe, and the former Soviet Union, and has published widely on subjects as diverse as the development of indigenous knowledge and famine early warning systems, to the role of military forces in disaster relief. He was the founder and manager of the World Disasters Report and played a key role in initiating and developing both the Code of Conduct for Disaster Workers and the Sphere humanitarian standards.

Peter Walker @ ICRC 